\title{
Mães no cárcere: percepção de vínculo com os filhos
}

\author{
Mothers in prision: link perception with sons
}

\section{Madres en prisón: percepción enlace con hijos}

\section{Indiara Ribeiro Soares*}

Faculdade Meridional - IMED, Passo Fundo, Rio Grande do Sul, Brasil

\section{Cláudia Mara Bosetto Cenci**}

Faculdade Meridional - IMED, Passo Fundo, Rio Grande do Sul, Brasil

\section{Luiz Ronaldo Freitas de Oliveira***}

Faculdade Meridional - IMED, Passo Fundo, Rio Grande do Sul, Brasil

\begin{abstract}
RESUMO
O presente estudo relata histórias de vida de mães que cumprem pena em regime fechado, tendo por objetivo identificar sua percepção dos vínculos mantidos com os filhos durante o período de reclusão. Nesse período, as mães deixam de exercer os cuidados necessários sob os filhos, ocorrendo o rompimento das funções maternas. Trata-se de um estudo de caráter qualitativo, exploratório e descritivo que utilizou como estratégia, para coleta de dados, a entrevista semiestruturada, que foram gravadas e transcritas para categorização e análise. Foi identificado que a percepção sobre a importância da maternidade e a necessidade de cuidar dos filhos serviu de motivação para o cumprimento da pena e superação dos limites impostos pelo sistema carcerário.
\end{abstract}

Palavras-chave: vínculo afetivo, mães e filhos, cárcere feminino.

\section{ABSTRACT}

This study reports on life stories of mothers who were convicted in closed regime, aiming to identify their perception of the ties maintained with the children during the confinement period. During this period, mothers fail to exercise reasonable care in children, occurring disruption of maternal functions. It is a qualitative, exploratory and descriptive study that used as a strategy, to collect data, semi-structured interviews, which were recorded and transcribed for analysis and categorization. It was identified that the perception of the importance of motherhood and the need to care for children served as the motivation for serving the sentence and overcoming the limits imposed by the prison system.

Keywords: affective Bond, mothers and children, women's prison.

\section{RESUMEN}

Este estudio informa sobre historias de vida de las madres que fueron condenados en régimen cerrado, con el objetivo de identificar la percepción de los vínculos que mantiene con los niños durante el período de confinamiento. Durante este período, las madres dejan de actuar con 
diligencia razonable en los niños, que se producen interrupción de las funciones maternas. Se trata de un estudio cualitativo, exploratorio y descriptivo que utiliza como estrategia, para recopilar datos, entrevistas semi-estructuradas, que fueron grabadas y transcritas para su análisis y categorización. Se identificó que la percepción de la importancia de la maternidad y la necesidad de cuidar a los niños sirvió de motivación para el cumplimiento de la pena y la superación de los límites impuestos por el sistema penitenciario.

Palabras clave: bond afectiva, las madres y los niños, la cárcel de mujeres.

\section{I ntrodução}

Os dados do Ministério da Justiça (2014) apontam que há um grande número de mulheres encarceradas em todo o território nacional. Segundo Levantamento Nacional de informações penitenciário (INFOPEN) ligado ao Ministério da Justiça (2014), já ultrapassa de 37.380 mulheres encarceradas nas mais diversas regiões do Brasil.

As condenadas à reclusão são afastadas de seus filhos, os quais passam a receber cuidados, na maioria das vezes, de familiares. Os dados apresentados pelo Ministério da Justiça (2014) revelam uma situação de exclusão e discriminação das mulheres encarceradas, embora diversos documentos internacionais e regionais recomendem que se preste maior atenção às questões das mulheres que se encontram na prisão, inclusive no tocante aos seus filhos. No Brasil, cerca de $80 \%$ delas são mães e isso resulta na perda ou fragilização das relações familiares, pois grande parte das mulheres são simplesmente abandonadas na prisão.

Historicamente, o sistema carcerário é considerado um ambiente de perigo, de desamparo e de antecipação da morte, privando a liberdade e provocando terríveis tormentos aos condenados (Bitencourt, 2011). Atualmente, o sistema carcerário apresenta situação de superlotação, precariedade, não respeito aos direitos individuais do preso, demonstrando o descaso do poder público e a falta de investimento nos presídios brasileiros (Assis, 2007). No Brasil a primeira prisão para mulheres surgiu no Rio de Janeiro em 1942 e recebeu o nome de reformatório especial. Essa instituição ficava longe das prisões masculinas e sob a administração de freiras que garantiam a higiene, a disciplina e a educação das apenadas. Os reformatórios seguiam o modelo de casas de conventos e as mulheres encaminhadas a esses lugares eram tratadas como irmãs desgarradas, que não precisavam de castigo, mas sim de cuidados aliados à prática da oração e afazeres domésticos (Soares \& Ilgenfritz, 2002).

O sistema prisional não foi construído pensando em atender à demanda feminina, mas tendo em vista o alto número de mulheres encarceradas, fica claro que elas fazem parte da realidade, marcada 
pela violência e exclusão social (Miranda, Vargas \& Viana, 2004). Contudo, a mulher quando presa é colocada em lugares com maior vulnerabilidade, a qual fica exposta a precariedade e superlotação. Conforme Barcinski (2012), as mulheres que são mães, sujeitam-se as instituições precárias e rejeitam estar em instituições com mais recursos e afastadas, para não perderem os vínculos com os seus familiares.

\section{Formação e manutenção dos vínculos entre mães e filhos}

O vínculo afetivo se constitui a partir dos laços duradouros com pessoas muito próximas das relações interpessoais. Ele se desenvolve por meio da capacidade emocional e psicológica da criança e, também, pelos cuidados, pelo olhar e pela responsabilidade que os cuidadores tratam as emoções das crianças (Ramires \& Schneider, 2010). O apego é a aproximação e o contato com uma determinada realidade afetiva e o objetivo é estabelecer segurança. É considerado um mecanismo básico, porque tem o papel de oferecer, através da figura de apego, respostas que supram as necessidades de alimentação e sexualidade, podendo ter controle do ambiente em que a criança se encontra. As ações proporcionam sentimentos de segurança e fortificam os laços com a figura de apego (Ainsworth, 1989).

Tanto o vínculo quanto o apego são estados internos, representados por figuras significativas, pois é nos primeiros anos de vida que a criança começa a se autorregular. A mãe representa segurança e limite, orienta o bebê, dá espaço, permite e restringe impulsos primitivos (Oliveira, 2000). Assim, a segurança que vai se estabelecendo entre a figura de apego e a criança é considerada como base segura, a qual será levada para toda a vida. Os filhos precisam de um ambiente que garanta condições para explorar o mundo externo e, quando se sentirem ameaçados, possam retornar à base segura para serem recebidos e confortados (Bowlby, 1989).

Para que o sujeito possa crescer mentalmente saudável (Bowlby \& Ainsworth, 1992) a criança recém-nascida precisa experimentar um ambiente aconchegante, intimista, de relacionamento contínuo com a mãe ou cuidadora, em que ambas encontrem satisfação e prazer. É no primeiro ano de vida que a criança se constitui para se tornar independente e a figura materna é a principal para essa independência, sendo recíproca entre elas tal ligação, que pode ser notada pelo sugar, pelo agarrar e por meio de sinalizações como o sorrisso e o choro (Bowlby, 1989). Para o autor, a relação entre os pais e a criança se estabelece por meio de um conjunto de sinais inatos do bebê, que exigem uma proximidade entre eles para se criar um vínculo afetivo. Os primeiros contatos e observações 
correspondidas dos bebês com os cuidadores afetam o estilo de apego, que começa se constituindo na infância e vai perdurar durante a vida dessa criança.

Conforme Ainsworth (1989) a base para os futuros relacionamentos íntimos da criança é construída pelos seus cuidadores primários. A autora para investigar a relação vincular entre mãe e filho desenvolveu o método chamado situação estranha, em que as reações da criança com os seus cuidadores primários eram observados. Obteve as seguintes categorias: (1) grupo seguro, (2) grupo ambivalente ou resistente, (3) grupo evitativo e (4) grupo desorganizado ou desorientado. O primeiro grupo (seguro) é justamente aquele que dispõe de cuidadores atentos e afetivos. A criança se sente segura em um ambiente que possa ser explorado de maneira entusiasmada e, quando se sente insegura, recorre aos cuidados que representam o apego e a confiança. As crianças do grupo seguro quando são separadas das suas figuras de apego se sentem incomodadas, mas não de modo exagerado, pois as características dos cuidadores são de cooperação, de orientação e de independência para a criança. $O$ segundo grupo (dos resistentes e ambivalentes), antes de ser separado dos cuidadores, reagiu de maneira imatura e não se mostrava entusiasmado para explorar o ambiente em que se encontrava, mas focou a atenção de maneira preocupada para os cuidadores. As crianças ficavam incomodadas quando separadas dos cuidadores, sem tentar aproximação com estranhos e, quando os cuidadores retomavam o contato, elas tinham dificuldade de aproximação e demonstravam irritação. As crianças do terceiro grupo (evitativo) brincavam tranquilamente, socializavam pouco com os cuidadores e se mostravam abertas para contato com estranhos quando separados dos cuidadores e, ao retomarem o contato com eles, não os procuravam. O quarto grupo, caracterizado por desorganizado ou desorientado, é de crianças que tiveram experiências negativas em sua infância e que, apresentaram comportamentos contraditórios ou incoerentes para lidar com a separação. Na presença dos cuidadores, elas apresentaram impulsividade, brabeza, expressão confusa, apreensão e perturbação. Diante dos grupos apresentados, pode-se observar o quanto um ambiente aconchegante e com segurança, principalmente da figura materna ou substituto com a criança é importante. Tal estrutura tem impacto no desenvolvimento individual da criança, para que futuramente possa ter um bom desenvolvimento em sua vida social, familiar e em seus futuros relacionamentos (Dalbem \& Dell'Aglio, 2005). 


\section{Função materna na constituição do psiquismo do sujeito}

O tema da constituição psíquica foi abordado por Freud (1900/1982), o qual afirmava que para ter um filho era necessário amar o que somos o que fomos e o que gostaríamos de ser, assim como amar aqueles que de nós cuidaram, para poder investir narcisicamente numa criança. Para (Mondardo \& Valentina, 1998) os pais exercem cuidados permanentes sobre os filhos, mesmo após eles terem construído certo grau de desenvolvimento e independência em suas vidas. Esses cuidados são importantes para a saúde de qualquer criança, pois educar uma criança não é tarefa fácil. A família tem como obrigação, além de suprir necessidades básicas como alimentar, proteger e dar abrigo, de proporcionar um ambiente em que a criança possa desenvolver com maior facilidade suas atividades físicas, mentais e sociais. A maneira como as mães demonstram seus sentimentos para o bebê (Sánchez, 2012) é constituída pelas experiências pessoais que vivenciaram ou ainda estejam vivenciando com seus pais. É por meio deste relacionamento parental que se percebe como os pais se vinculam aos filhos, suprindo ou não as necessidades físicas e emocionais da criança.

Zimerman (2001) afirma que há vida psíquica intrauterina e o feto sente os estímulos transmitidos pela mãe, tanto os internos como os externos. O bebê faz movimentos no útero materno em resposta aos estímulos que lhe são propostos e responde ao toque dos dedos da mãe no ventre. Durante a gestação (Aragão, 2007) o bebê é um estranho para mãe e nesse período ela passa a projetar suas idealizações por meio da sua história de infância para incluir o feto como parte do seu corpo. Os movimentos que a criança realiza servem para que a mãe possa atribuir significado à gravidez e para que se estabeleça comunicação entre o bebê e ela.

Como a maioria dos bebês interage mais com a mãe do que com o pai, nos primeiros anos de vida o modelo de self que o bebê constitui com a mãe é o que exerce maior influência sobre ele, porque começa a constituir suas primeiras representações mentais. Essa interação entre mãe e filho vai dando forma ao psiquismo do bebê, pois oferece qualidade, consistência, certeza e estabiliza o afeto entre eles. Para o bebê existir, logo que nasce precisa que a mãe exerça sobre ele seus cuidados maternais (Bowlby, 1989). A função materna (Aragão, 2004) se dá a partir do momento em que o bebê é gerado e passa a ser reconhecido como tal. Quem faz esse processo inicial na vida da criança é a mãe, a qual lhe supre as necessidades sempre que necessário e Ihe dá limites, mostrando que ele não é único e que, a partir do seu nascimento, começa a dividir seu espaço com os demais. O momento em que a mãe o reconhece e passa a lhe dar todo o suporte necessário é decisivo para o desenvolvimento do psiquismo do bebê, porque todas as interações entre eles vão dando 
início à constituição do psiquismo. É importante que a constituição inicial ocorra da melhor forma possível, podendo a mãe lhe oferecer confiança, segurança, amor e ternura para que seu psiquismo se desenvolva saudável, pois ele inicia na infância e irá perdurar por toda a vida do indivíduo (Bowlby 1989; Mondardo \& Valentina, 1998).

\section{Método}

A pesquisa é de caráter qualitativo, exploratório e descritivo, que aborda aspectos tais como opiniões, atitudes, crenças, motivos e valores (Ruiz, 2013). As participantes foram cinco mulheres que cumprem pena em regime fechado num presídio feminino no norte do Estado do Rio Grande do Sul e indicadas pela Psicóloga do local. Sendo mães com faixa etária de 18 a 50 anos e com filhos de 1 a 10 anos. Foi utilizada, como instrumento para coleta dos dados, a entrevista semiestruturada com a intenção de construir a "história de vida" de cada uma das mães e levantar questões objetivas e subjetivas que abordavam a vincularidade entre mães e filhos quando estas se encontram em situação de cárcere (Flick, 2009). As entrevistas foram realizadas nas dependências do presídio, gravadas, transcritas e sistematizadas a partir da análise de conteúdo (Bardin, 2010) seguindo os seguintes passos: $\left(1^{\circ}\right)$ Pré-análise: foi realizada a leitura flutuante do material das entrevistas; $\left(2^{\circ}\right)$ Exploração do material: nesta etapa foi realizada a administração sistemática das decisões tomadas, num processo de ida e vinda do material de análise à teoria, com o intuito de compatibilizar os dados empíricos e manifestos em pressupostos teóricos e seus respectivos referenciais explicativos; $\left(3^{\circ}\right)$ Tratamento dos resultados: foram realizadas inferências e interpretações, pois os resultados brutos foram tratados de maneira a serem significativos e válidos.

Este estudo foi desenvolvido observando os preceitos éticos da Resolução do Conselho Nacional de Saúde 466/12, sendo aprovado pelo Comitê de Ética de Pesquisa da Faculdade Meridional, com o parecer número 720.243. Os pesquisadores observaram todos os cuidados necessários para o bem-estar das participantes e as mães foram informadas antecipadamente sobre a pesquisa, e concordando em participar, assinaram o Termo de Consentimento Livre e Esclarecido.

\subsection{Apresentação das histórias de vida}

Primeira história: Sônia ${ }^{1}, 40$ anos, ensino fundamental incompleto, mãe de seis filhos, sendo a mais nova uma menina de um ano e sete meses. Cumpre pena em regime fechado há um ano e oito meses e tem diagnóstico de HIV positivo, trabalha na prisão com artesanato 
para ajudar na redução da pena. Relatou que conheceu o atual companheiro na prisão, o qual também é portador do vírus HIV e do qual engravidou da filha mais nova. Durante o período da gestação, foi beneficiada com suspensão de pena até o nascimento da menina e após retornou para o sistema penitenciário. A filha não é portadora do vírus HIV e está sob os cuidados da irmã do marido. Sônia refere não ter feito uso de drogas durante a gestação e descreve a filha como "uma boneca é uma princesa". Sente muita saudade, mas sabe que a menina está sendo bem cuidada pela cunhada. O contato entre ela e a filha é por meio de fotos, cartinhas e recados trazidos por familiares de outros presos durante as visitas. Comenta que o contato é complicado e explica que antes a avó levava a menina até o presídio para visitá-la, mas ela faleceu e agora fica inviável comprometer outros familiares nessa tarefa, pois muitos não aceitam a situação e nem o fato de as crianças frequentarem o ambiente em que a mãe se encontra. Ela diz:

"Se ela vier aqui, vai sair chorando, porque eu vejo várias crianças saírem assim, e vou me agoniar mais, então prefiro que não venham me visitar, mas eu sofro muito. "Quando fui presa me abalei muito, chorei muito, até hoje tem dias que eu vou para cama e não saio pra nada, pensando em como ela está e o que está fazendo".

Sônia se sente culpada por estar longe da filha e pensa que não precisava ter que feito o que fez para estar presa, busca na religião apoio para se sentir mais leve e tentar proteger a filha de longe. Em relação à educação e aos limites transmitidos à filha, relata que foram bem conduzidos enquanto esteve junto com ela.

“Hoje sou a melhor escola para a minha filha. Tem gente que diz que a família é o espelho, mas depende da situação, porque a minha família era bem estruturada, eu não tinha necessidade de mexer em nada de ninguém, sempre tive de tudo, nunca faltou nada, mas as companhias me influenciaram muito e caí nessa vida. Eu destruí a minha vida porque me tornei dependente de drogas. Entrei no tráfico porque queria dar luxo aos meus filhos e apenas coisas boas".

Ela tem esperança que a filha faça totalmente o contrário do que ela fez, que possa estudar, que sejam alguém na vida e dar orgulho à família. Destaca que passou mais tempo longe do que perto da filha e não se considera a figura de identificação, mas pretende ser diferente e se tornar referência após sair da cadeia. Considera-se uma mãe ausente: 
“Vejo que dei pouca atenção de mãe à minha filha. Cadê a mãe para dar força, para ajudar no tema, mãe para tudo? Um filho não precisa de uma mãe um ou dois anos, mas precisa da mãe sempre e ela não tem culpa dos meus erros".

Planeja sair da prisão e buscar um emprego para recuperar o afeto da filha, dar carinho, amor e atenção.

Segunda história: Cleuza, 23 anos, ensino médio completo, mãe de um menino de um ano e cinco meses e está cumprindo pena em regime fechado há três anos. Foi detida juntamente com o marido por envolvimento em assalto. Após um ano na prisão, engravidou e percebeu a gestação aos quatro meses. Aceitou normalmente, mas tinha a preocupação pelo fato de estar presa e não saber como conduzir a gravidez e os cuidados com a criança. Relatou que era usuária de drogas e que parou de utilizar alguns meses antes de descobrir a gravidez. Deu a luz ao bebê no hospital e deixou aos cuidados da sogra, que obteve a guarda provisória. Ao retornar para a prisão chorava muito e teve que secar o leite, pois não podia amamentar o bebê diariamente. Após o nascimento do filho, se separou do pai da criança e durante cinco meses conseguiu ter contato com o filho nas visitas assistidas, o que atualmente não acontece pelo fato da sogra levar o menino somente para visitar o pai.

“Faz um ano que não vejo meu filho de perto, não pego no colo, é horrível. Eu vejo meu filho de longe nos dias de visita quando está com o pai, ele não traz o menino nem perto para eu ver".

Explica que a figura da avó é a mais forte e significativa para a criança, ele é bem apegado e está sendo bem cuidado por ela: "Mas tenho medo que no futuro o meu filho não me reconheça como mãe". Afirmou que deseja sair da prisão para ter o filho de volta e, se precisar, irá lutar pelos seus direitos. Sente muita raiva de estar ali, tristeza, perda e pensa que um dia vai conseguir sair da prisão e ficar com o filho.

Terceira história: Jurema, 33 anos, ensino fundamental incompleto, tem dois filhos sendo um menino de nove anos, um de cinco anos e está grávida de cinco meses. Cumpre pena em regime fechado há quatro anos. Os filhos estão sob os cuidados da sua irmã que tem a guarda das crianças. Relatou que os filhos estão sendo bem cuidados: "A minha irmã está sendo mais mãe para os meus filhos do que eu, carinho de mãe não se substitui, mas não tenho nenhuma queixa dos cuidados que recebem". Jurema tem contato com os filhos uma vez 
por mês e percebe nas visitas que as crianças também chamam a tia de mãe, mas não se importa, porque são familiares e não pessoas estranhas. No momento está grávida do companheiro, que também cumpre pena em regime fechado no mesmo presídio. Percebeu a gravidez logo no início e procurou assistência médica e psicológica para garantir saúde ao bebê. Está planejando o nascimento e os cuidados do filho: "Ele ficará com a minha sogra, a gente não tem muita escolha ou fica com a família da gente ou vai para adoção". Explica que a gestação é tranquila, não há nenhuma complicação, sente-se ansiosa com a chegada do bebê. Mas demonstra estar feliz com a vinda da criança e reforça: "Era um filho que eu queria, mas não nesse lugar". Não gostaria de ver os filhos na cadeia, pois pensa que pode ocorrer uma rebelião ou alguma briga e preocupa-se com o que possa acontecer. Refere que após a prisão se fortaleceram os vínculos entre ela e os filhos, pois eles estão se comportando melhor, obedecendo mais e estão bem na escola. Porém, gostaria de estar sempre junto deles. "Sei que eles sentem muito minha falta, mas assim estão aprendendo a crescer, estão amadurecendo, não se comportando mais só como crianças". Nunca achou que iria passar por isso, mas sabe que os filhos têm muita admiração por ela e os orienta: "Não devem fazer coisas erradas para não repetir o mesmo erro que eu, desobedeci por isso estou aqui, mas amo muito os meus filhos e desejo que eles sejam alguém na vida". Pretende sair da prisão e ficar com os filhos, pois sente saudades, sofre, lamenta muito pelas coisas erradas que fez e queria estar com eles.

Quarta história: Antônia, 24 anos, ensino fundamental incompleto, tem um filho de três anos e está cumprindo pena em regime fechado há dois meses por envolvimento no tráfico de drogas. Trabalha na prisão como cozinheira para reduzir à pena. Ela e o companheiro foram detidos juntos e pelo mesmo motivo. Inicialmente, deixou o filho sob os cuidados da sua mãe e no momento está sob os cuidados da sogra. Sente-se inconformada e chocada pelo que aconteceu: "Tenho muito medo que meu filho me esqueça, mantenho contato com ele uma vez por semana durante duas ou três horas e o menino sempre sai chorando muito, querendo que eu saia também". Como faz pouco tempo que está presa, ainda não conseguiu pensar como será a relação com o filho, mas expressa sofrer muito por estar longe dele. Descreveu que no dia em que foi detida, junto com o pai da criança, o filho presenciou tudo do início ao fim e ficou muito chocado, apavorado, chorando muito. Agora, quando ele vê a polícia, corre e se esconde. Um dos maiores medos da mãe era que ninguém pudesse ficar com o filho e ele tivesse que ir para a adoção. Acredita que o filho penso que ela abandonou-o e não o quer mais, porque quando vai visitá-la ele pergunta: 
“Mãe você não quer mais ir para casa? Tu vai morar aqui? A polícia não deixa mais você ir pra casa? Por que você está aqui? Onde você dorme? O que você come? Por que aqueles homens ficam lá? Por que minha avó fica pelada quando chega aqui?".

Fica preocupada, pois ele pergunta tudo e muitas vezes ela não sabe o que dizer ou como explicar, pois é apenas uma criança. Relata que o filho ainda não fala todas as palavras: "Os avós não entendem com facilidade o que ele pede. Deve ser muito difícil, pois está se virando sozinho, não tenho noção de como ele está sendo cuidado e tenho muito medo que possam bater nele". Quando o menino está com ela, faz algumas coisas para chamar a atenção, como derrubar refrigerante nos pés dela, dar tapas e apresentar comportamentos diferentes do habitual: "Ele está rebelde, maroto, faz coisas que antes não fazia. E hoje estamos comprando ele com brinquedos e dinheiro que guarda até a próxima visita". Está muito ansiosa, abandonada, com saudade, sentindo muita dor, não gosta de chegar perto da porta, pois entra em desespero. Tem preocupação com o futuro e espera que o filho não chegue perto do mundo das drogas. Busca apoio na religião para poder aliviar tantas dúvidas que tem encontrado e para que mesmo distante do filho possa protegê-lo.

Quinta história: Flávia, 32 anos, ensino fundamental incompleto, tem duas filhas, sendo uma de onze anos e a outra de dois anos. Está cumprindo pena em regime fechado há dois anos sob a acusação de envolvimento em assalto. Trabalha na prisão como cozinheira para reduzir a pena. Recebe as filhas para visita uma vez por semana e fica com elas durante três horas. As filhas estão sob os cuidados da sua irmã, porque o pai das meninas também está preso em outra cidade. Relata que quando foi presa chorava muito e quase enlouqueceu, foi encaminhada para o psiquiatra, o qual the receitou remédios controlados que toma até hoje. Teve que interromper a amamentação da filha e esse processo foi muito doloroso:

"Quando parei de amamentar minha filha, tive febre, empedrou os seios, foi horrível. Quando o peito vazava eu sabia que estava na hora de amamentar, porque ela estava chorando com fome. Então minha irmã alugou uma mulher que tinha neném e aí ela amamentava a minha filha, isso foi muito doído, muito sofrido, porque estava aqui tirando e botando fora o leite, enquanto uma pessoa estranha amamentava minha filha".

Flávia frisou que, mesmo não estando com as filhas, sabe que estão bem cuidadas e se precisar de médico, remédios e outros cuidados a irmã faz o que for preciso. A filha pequena chama a tia de mãe e não 
é fácil ouvir chamando outra pessoa de mãe. "Durante a visita, na hora de dormir, ela não quer meu colo e sim o da minha irmã, às vezes eu peço 'filha da um beijo na mãe', ela dá primeiro na minha irmã e depois em mim". Sabe estar perdendo a melhor fase da filha, diz que a irmã procura mostrar as fotos da mãe para a criança, explica que sua mãe é a Flávia e que ela é sua dinda. A menina reconhece Flávia como mãe, quando vai às visitas, Ihe dá abraços, passa batom e a enche de marcas de beijos. Acredita que existe um vínculo forte entre elas, o sentimento que existe ali dentro da prisão é o mesmo que existe fora. Como meio de reduzir sua preocupação, tenta colocar na religião sua força e deixa que Deus proteja suas filhas. Sempre procura explicar a elas o melhor caminho, espera que jamais se envolvam com algo errado e, quando sair da prisão, irá conviver novamente com as filhas.

\subsection{Análise e discussão das histórias de vida}

As histórias foram analisadas a partir de quatro categorias que contemplam aspectos comuns entre as mães entrevistados: (1) A percepção sobre a maternidade; (2) Cuidado com os filhos; (3) Os filhos motivam na superação da pena e (4) Perspectiva de futuro.

\section{A percepção sobre a maternidade}

Os dados coletados, por meio das entrevistas com as mães encarceradas, mostraram que o sentido da maternidade se evidencia na percepção de que o afastamento decorrente do encarceramento enfraqueceu os vínculos entre mãe e filhos e comprometeu a relação de cuidado. Identifica-se essa afirmação na história quatro quando Antônia refere: "Tenho muito medo que meu filho me esqueça". Esta percepção da mãe se confirma na literatura, pois o vínculo se constitui a partir de laços duradouros com pessoas muito próximas (Ramires \& Schneider, 2010), e se desenvolve pela capacidade emocional e psicológica da criança, pelos cuidados, pelo olhar e pela responsabilidade. $\mathrm{O}$ modo como os cuidadores tratam a criança é fundamental para o seu desenvolvimento saudável.

O processo de separação entre mãe e filho, caracteriza a maternidade como dolorosa e gera sentimentos de perda e de impotência, conforme relato da mãe na história cinco: "Minha irmã alugou uma mulher e aí ela dava mama para minha filha, isso foi muito doído, muito sofrido, porque estava aqui tirando e botando fora o leite, enquanto uma pessoa estranha amamentava minha filha". Na história três Jurema reforça esta percepção referindo que sofre por estar distante dos filhos e preocupa-se em relação aos ensinamentos transmitidos aos filhos: "Não façam coisas erradas para não repetir o 
mesmo erro que eu, desobedeci por isso estou aqui, mas amo muito os meus filhos e desejo que eles sejam alguém na vida". Procura transmitir, em dias de visitas, seus sentimentos de carinho, afeto e conversa na tentativa de manter os laços maternos com eles. Nas histórias dois, quatro e cinco, as mães se sentem incapazes e com medo de perder seus filhos, pois temem não ser reconhecidas e que sejam esquecidas como mães. O medo de ser esquecida se evidencia ainda mais na história dois, pois a mãe engravidou no presídio e, quando o bebê completou cinco meses, ela rompeu o relacionamento com o pai da criança. Como o filho está sob os cuidados da avó paterna, ela só leva o neto para as visitas do pai, impossibilitando o contato entre mãe e filho. Na história quatro, a mãe afirma que ainda não conseguiu pensar como ficará o vínculo dela com o filho. "Estou aqui faz pouco tempo, mas tenho muito medo de ser esquecida, ou que ele pense que eu não o quero mais". Conforme Oliveira (2000) é nos primeiros meses de convivência entre mãe e filho que se desenvolve a percepção sobre a maternidade e surge a necessidade da vincularidade. No momento em que a criança começa a se autorregular, a mãe representa segurança e limite no processo de desenvolvimento, tendo papel fundamental na vida da criança.

Na história cinco, a mãe sempre se mostrou presente na vida da filha, mas após ser presa a filha passou a ser cuidada pela irmã. Reconhece que a menina está bem, mas sofre porque precisou desamamentar a filha muito cedo:

"Quando o peito vazava eu sabia que estava na hora de amamentar porque ela estava chorando com fome", ou nos dias de visita: "Durante a visita, na hora de dormir, ela não queria meu colo e sim o da minha irmã, às vezes eu peço 'filha dá um beijo na mãe', ela dá primeiro na minha irmã e depois em mim".

A percepção da mãe sobre a maternidade demonstra que a sua ausência em relação à filha está gerando perdas referentes à figura de apego. Bowlby (1989) afirma que a criança precisa se sentir cuidada para estabelecer entre ela e a figura de apego a chamada base segura, a qual vai Ihe proporcionar uma estrutura que será levada para o resto da vida.

Já nas histórias um e três, as mães demonstram satisfação pelos cuidados que os familiares exercem sobre os seus filhos, porém manifestam o desejo de sair da prisão e cumprir o seu papel. $\mathrm{Na}$ história um, a mãe mantém contato com a filha por meio de cartas e recados enviados por familiares de outros presos. Relata: "Sinto muita saudade, mas sei que a menina está sendo bem cuidada pela minha cunhada". Isso expõe que nunca exerceu completamente sua função de mãe: 
“Meu filho não tinha a mãe para ir numa reunião de colégio, para levá-lo ao médico. Cadê a mãe para dar força, para ajudar no tema, mãe para tudo. Um filho não precisa de uma mãe um ou dois anos, mas precisa da mãe sempre e eles não têm e é culpa dos meus erros".

Para Mondardo e Valentina (1998) os pais exercem cuidados permanentes sobre os filhos, mesmo após eles terem construído certo grau de desenvolvimento e independência em suas vidas, sendo tais cuidados importantes para a saúde de qualquer criança, pois educar uma criança não é uma tarefa fácil. Na história três, a mãe tem duas filhas e está grávida de cinco meses do companheiro, que também é presidiário no mesmo local. Atualmente, o contato dela com os filhos ocorre uma vez por mês. Os filhos estão sob os cuidados da irmã e sua percepção sobre a maternidade consiste na própria negação da função materna, sobre a qual afirma: "Ela está sendo mais mãe para os meus filhos do que eu. É ruim não estar com eles, mas acredito que este afastamento foi bom, isso pode ter fortalecido a nosso contato". Segundo Sánchez (2012) o comportamento e a maneira como a mãe demonstra seus sentimentos para com os filhos consiste nas experiências pessoais que vivenciou ou ainda esteja vivenciando com seus familiares.

As histórias de vida demonstram, nesta categoria, que a percepção sobre a maternidade é contraditória e confusa para as mães encarceradas. Numa atitude defensiva, para aliviar a dor da ausência dos filhos, elas terceirizam as funções maternas e justificam que os filhos estão bem por estar longe daquele lugar perigoso e hostil. Mas admitem que o afastamento enfraquece os vínculos entre mãe e filhos e comprometeu a relação vincular.

\section{Cuidado com os filhos}

Pode-se observar, por meio dos dados coletados, que as mães esperam que seus filhos se distanciem do mundo do crime, que estudem, sejam pessoas bem vistas pela sociedade e tenham um futuro promissor. Na primeira história de vida, o sentimento de medo e insegurança sobre o futuro dos filhos se evidencia na fala da Sônia: "A família não é espelho para o sujeito, pois eu era de uma família estruturada e entrei para o mundo do crime pelas companhias". Ainsworth (1989) reforça a importância da estrutura familiar, no cuidado com os filhos, ao afirmar que um ambiente aconchegante e com segurança, é importante e tem impacto no desenvolvimento individual da criança, para que futuramente possa ter um bom desenvolvimento na sua vida social, familiar e em seus futuros 
relacionamentos. Sônia reforça a sua preocupação em relação aos cuidados com os filhos e considera a prisão um lugar de destruição da família e optou por não receber a visita dos filhos, na tentativa de prevenir o contato com esse mundo desde cedo: "Eu vou me agoniar mais, então optei por eles não virem me visitar, eu sofro muito". Ela deixa que a irmã passe os valores e os limites aos filhos a fim de que eles façam totalmente o contrário do que ela fez e que, apesar dos erros que cometeu, deseja sentir orgulho dos filhos.

Nas histórias três e cinco, Jurema e Flávia demonstram saudade dos filhos, sofrem e lamentam por estar presas: "E que [os filhos] não devem fazer coisas erradas para não repetir o mesmo erro que eu". Elas têm pretensão de sair para cuidar dos filhos, mas relatam que estão perdendo a melhor fase da vida dos filhos. Na história quatro, Antônia expõe que o filho de três anos presenciou o momento em que os pais foram presos, não entende por que estão naquele lugar e por quê não está cuidando dele. Faz muitas perguntas sobre o ambiente, deixando-a sem respostas: "Ele está rebelde, maroto, faz coisas que antes ele não fazia". Gomes e Bosa (2010) constataram que as primeiras experiências de cuidados vividas na infância, com os pais, são as que influenciam no modo de criação dos filhos. Antônia tem muito medo do futuro do filho e espera que ele nunca chegue perto das drogas e que possa esquecer esse momento negativo vivenciado por eles. Cleuza na história dois também tem medo do futuro do filho, mas isso se torna ainda mais doloroso por não ter contato algum com ele e não ter a certeza se quando sair da prisão irá conseguir cuidar do filho e conviver com ele. "É difícil esperar algo do filho futuramente, já que ele não está sendo cuidado pela mãe". Afirma Cleuza.

Em relação ao cuidado com os filhos percebe-se que as mães encarceradas utilizam a negação como meio de defesa psicológica. A responsabilidade materna e as questões familiares são evitadas, na tentativa de diminuir o sofrimento e amenizar a saudade.

\section{Os filhos motivam na superação da pena}

As mães encarceradas expressam que após serem presas sentem-se sozinhas, abandonadas pelos familiares e sofrem, principalmente, com o afastamento dos filhos. Os filhos se tornam os principais motivadores para as mães lutarem pela saída da prisão. Buscam trabalhar dentro da prisão como cozinheiras, nos serviços gerais ou como artesãs para ajudar na redução da pena, na intenção de superar o tempo perdido e recuperar os laços entre mãe e filho o mais rápido possível.

Verifica-se nas histórias um, quatro e cinco, em que Sônia, Antônia e Flavia trabalham na cozinha, nos serviços gerais e realizam 
artesanatos para reduzir a pena. Trabalhar no sistema prisional serve para evitar a depressão e o sentimento de desvalia, bem como, apegam-se à religião como meio para continuar lutando na superação das dificuldades. Convivendo com pessoas estranhas e esperando os dias passar, longe dos filhos e sem saber o que estão fazendo, de que estão precisando ou se estão sendo bem cuidados. Um ponto importante na história um, foi à saída de Sônia para dar a luz à filha e, durante o período da gestação, conseguiu ficar sob a suspensão da pena. Essa condição, para as apenadas, é interpretada como recomeço e possibilidade de superação da rotina prisional.

$\mathrm{Na}$ história dois, após o nascimento do filho de Cleuza, a criança passou a ser cuidado pela sogra e Sônia faz planos para retomar a guarda do filho após o cumprimento da pena: "Sofro muito sem o meu filho, quero muito poder sair daqui e resgatar o meu bebê, é o que me motiva para sair desse lugar". Na história três, Jurema está grávida de cinco meses e relata que os filhos de nove e cinco anos estão sendo bem cuidados pela irmã: "A gente não tem muita escolha ou fica com a família ou vai para adoção". Jurema relata que "não vê a hora de sair da prisão para cuidar dos meus filhos".

Nesta categoria a maternidade gera esperança e desejo de superação da pena pelas mães encarceradas. O vínculo materno devolve a esperança de vida nova e retomada frente aos obstáculos que a situação prisional apresenta.

\section{Perspectiva de futuro}

Em relação à perspectiva de futuro, nas histórias um, dois e cinco, as mães têm medo de no futuro, não serem uma figura representativa para os filhos. Isso gera desconforto, sofrimento e sentimento de perda, já que devido o afastamento dos filhos não conseguem exercer os cuidados necessários e, muito menos, realizar a manutenção dos vínculos duradouros. Na história cinco, Flávia permaneceu poucos meses com a filha de dois anos e refere que a criança demonstra sentimentos de amor por ela, mas no momento de dormir prefere o colo da tia: "Quando peço um beijo, ela primeiro beija a tia e depois a mãe". Nesse caso, preferir a tia é uma ação da criança que proporciona sentimento de segurança, fortifica os laços com a figura de apego, e por parte da mãe, desperta a perspectiva de futuro em relação à maternidade (Ainsworth, 1989; Oliveira, 2000). Nas histórias três e quatro, em que os filhos são maiores de dois anos, pode-se verificar a dificuldade que as crianças têm em aceitar uma nova figura representativa. Elas choram muito e não compreendem porque a mãe precisa ficar no presídio. Esse sentimento faz com que as mães tenham receio das visitas e depositem no futuro a possibilidade de conviver plenamente com os 
filhos. Na história três, o filho pergunta à mãe: "Você não quer mais ir para casa? Tu vai morar aqui? A polícia não deixa mais você ir pra casa? Por que você está aqui? Onde você dorme? O que você come? Por que aqueles homens ficam lá?". Perguntas que direcionam para a perspectiva de futuro e faça com que a sofra e sinta-se muito insegura sobre a relação que irá constituir futuramente com os filhos. Dalbem e Dell'Aglio (2005) afirmam que as crianças que dispõem de cuidadores atentos e afetivos quando são separados das suas figuras de apego se sentem incomodadas e inseguras, demonstrando a necessidade e interesse de recuperar a relação numa perspectiva de futuro.

Frente às histórias apresentadas, a perspectiva de futuro circula em torna do cuidado e da manutenção dos vínculos com os filhos. As mães pretendem sair da prisão e conviver com os filhos, tendo a esperança de construir um bom vínculo com os mesmos. Assim, as mães numa perspectiva de futuro podem se tornar ou voltar a serem as principais figuras de apego e com vínculos sólidos para eles.

\section{Considerações finais}

O presente estudo abordou a percepção de vincularidade entre mães encarceradas e seus filhos. Por meio da construção da história de vida das mães foi possível constatar que a percepção sobre a maternidade, o cuidado com os filhos, a superação da pena e a perspectiva de futuro são aspectos que justificam a importância da atenção aos vínculos entre mães e filhos.

As mães após serem recolhidas para cumprir pena em regime fechado encontram dificuldades para manter os vínculos com os filhos, o que compromete os cuidados exercidos sobre eles e enfraquece suas relações familiares. Por outro lado, os filhos são os principais motivadores para que as mães suportem o rigor e a privação no cumprimento da pena. Elas esperam que os filhos possam ter um futuro distante do mundo do crime, mas estão longe deles para exercer o cuidado que é destinado a terceiros, e na maioria das histórias de vida, aos seus familiares.

Foi constatado também que as mães utilizam a 'negação' como mecanismo de defesa para diminuir o sofrimento. E buscam apoio na religião como tentativa de conforto em relação ao afastamento dos filhos e a privação das relações familiares.

A importância da percepção da figura materna, como suporte para a criança, se evidenciou nas histórias das mães que relataram perceber que os filhos esperam a transmissão de valores, limites e um ambiente seguro. A manutenção dos vínculos entre mães e filhos, mesmo em situação de cárcere, é importante na superação da pena, pois as mães relataram que ao saírem da prisão, pretendem retomar 
suas vidas junto aos filhos, a fim de que os cuidados necessários possam ser restaurados.

Portanto, mesmo diante dos limites que o estudo apresenta, foi possível perceber que a situação carcerária é uma das questões mais complexas da realidade social brasileira, principalmente no que diz respeito à realidade das mães encarceradas. A necessidade da humanização das condições carcerárias depende da promoção de um modelo de políticas públicas de saúde, de educação, de trabalho, de cultura, de esporte, de assistência social e de acesso à justiça. Diante dessas constatações pretende-se contribuir com o entendimento sobre a importância da manutenção dos vínculos entre mães e filhos. Isto para manter a percepção positiva sobre a maternidade, a importância do cuidado com os filhos, o entendimento de que os filhos motivam na superação da pena e na perspectiva de futuro após o cumprimento da pena.

\section{Referências}

Ainsworth, M. D. S. (1989). Anexos além da infância. Departamento de Psicologia da Universidade de Virginia. Associação Americana Psicologia. 44(4), pp. 709-716.

Aragão, R. O. (2004). O bebê, o corpo e a linguagem. São Paulo: Casa do psicólogo.

Aragão, R. O. (2007). A Construção do Espaço Psíquico Materno e seus Efeitos Sobre o Psiquismo Nascente do Bebê. Dissertação de Mestrado em Psicologia Clínica. Pontifícia Universidade Católica de São Paulo.

Assis, R. D. (2007). A Realidade Atual do Sistema Penitenciário Brasileiro. Revista CEJ, Brasília, 2(39), pp. 74-78.

Barcinski, M. (2012). Mulheres no tráfico de drogas: a criminalidade como estratégia de saída da invisibilidade social feminina. Contextos Clínicos, 3(5), pp. 52-61.

Bardin, L. (2010). Análise de Conteúdo. Lisboa: Edições, 70.

Bitencourt, C. R. (2011). Falência da pena de prisão: causas e alternativas. São Paulo: Saraiva.

Bowlby, J. (1989). Uma base segura: aplicações clínicas da teoria do apego. Porto Alegre: Artes Médicas.

Bowlby, J., \& Ainsworth, M. (1992). The origins of attachment theory. Developmental Psychology, 28(2), pp. 759-775.

Dalbem, J. X. \& Dell'Aglio, D. D. (2005). Teoria do apego: bases conceituais e desenvolvimento dos modelos internos de funcionamento. Arquivos Brasileiros de Psicologia, 57(1), pp. $12-24$.

Flick, U. (2009). Introdução à pesquisa qualitativa. Porto Alegre: Artmed. 
Freud, S. (1900/1982) Os sonhos: Além da interpretação de sonhos. Rio de Janeiro, I mago.

Gomes, V. F., \& Bosa, C. A. (2010). Representações mentais de apego e percepção de práticas parentais por jovens adultas. Psicologia: Reflexão Crítica, 23(1), pp. 67-84.

Ministério da Justiça (2014). Levantamento Nacional de informações penitenciárias. INFOPEN-BRASIL - junho de 2014. Recuperado em 06 de outubro, 2015, de: http://www.justica.gov. br/noticias/mj-divulgara-novo-relatoriodo-infopen-nesta-terca-feira/relatorio-depen-versaoweb. pdf/view.

Miranda, A. E., Vargas, P. R. M., \& Viana, M. C. (2004). Saúde sexual e reprodutiva em penitenciária feminina, Espírito Santo, Brasil. Revista Saúde Pública, 38(2), pp. 255-260.

Mondardo, A. H., \& Valentina, D. D. (1998). Psicoterapia infantil: ilustrando a importância do vínculo materno para o desencolvimento da criança. Psicologia: Reflexão e Crítica. Porto Alegre, 11(3), pp. 113-126.

Oliveira, R. A. (2000). Do vínculo às relações sociais: Aspectos psicodinâmicos. Análise Psicológica, 2(18), pp. 157-170.

Ramires, V. R. R. \& Schneider, S. M. (2010). Revisitando alguns conceitos da teoria do apego: comportamento versus representação. Psicologia: Teoria e Pesquisa, 26(1), pp. 25-36.

Ruiz, J. A. (2013). Metodologia Científica. São Paulo: Atlas.

Sánchez, P. V. (2012). La Experiencia vinculante afectiva del sujeto adolescente infractor. Revista Latinoamericana de Ciencias Sociales, Niñes y Juventud, 10(1), pp. 453-465.

Soares, B. M., \& Ilgenfritz, I. (2002). Prisioneiras: vida e violência atrás das grades. Rio de Janeiro: Garamond.

Zimerman, D. (2001). Vocabulário contemporâneo de psicanálise. Porto Alegre: Artmed.

\section{Endereço para correspondência \\ Indiara Ribeiro Soares}

Faculdade Meridional - IMED

Curso de Psicologia

Rua Senador Pinheiro, 304, CEP 99070-220, Passo Fundo - RS, Brasil

Endereço eletrônico: indhys1@gmail.com

\section{Cláudia Mara Bosetto Cenci}

Faculdade Meridional - IMED

Curso de Psicologia

Rua Senador Pinheiro, 304, CEP 99070-220, Passo Fundo - RS, Brasil

Endereço eletrônico: claudia.cenci@imed.edu.br

\section{Luiz Ronaldo Freitas de Oliveira}

Faculdade Meridional - IMED

Curso de Psicologia

Rua Senador Pinheiro, 304, CEP 99070-220, Passo Fundo - RS, Brasil

Endereço eletrônico: ronaldo@imed.edu.br 
Indiara Ribeiro Soares, Cláudia Mara Bosetto Cenci, Luiz Ronaldo Freitas de Oliveira

Recebido em: 19/05/2015

Reformulado em: 07/10/2015

Aceito para publicação: 22/10/2015

\section{Notas}

* Psicóloga, aluna egressa do Curso de Psicologia da Faculdade Meridional - IMED, Passo Fundo, Rio Grande do Sul, Brasil.

** Doutorando em Psicologia pela PUCRS. Professora do Curso de Psicologia da Faculdade Meridional - IMED.

*** Doutorando em Psicologia Clínica pela UNISINOS. Professor e coordenador do Curso de Psicologia da Faculdade Meridional - IMED. Passo Fundo, Rio Grande do Sul, Brasil.

${ }^{1}$ Os nomes são fictícios para preservar a identidade das participantes. 